\title{
Conservation and biomonitoring in the Vikramshila Gangetic Dolphin Sanctuary, Bihar, India
}

\author{
Sunil K. Choudhary, Brian D. Smith, Subhasis Dey, Sushant Dey and Satya Prakash
}

\begin{abstract}
From March 2001 to December 2003 eight direct count surveys in an upstream direction were conducted for Ganges river dolphins Platanista gangetica gangetica in the Vikramshila Gangetic Dolphin Sanctuary, a c. $60 \mathrm{~km}$ long segment of the middle Ganges River in Bihar, India. The mean number of dolphins recorded during upstream surveys was $119.4 \pm$ SD 31.8 (range $88-174)$, with an encounter rate of 1.8 dolphins $\mathrm{km}^{-1}$ (range 1.4-2.8). During these surveys a rich diversity of other threatened aquatic wildlife was also documented, including the Indian smooth-coated otter Lutrogale perspicillata, gharial Gavialis gangeticus, a variety of freshwater turtles, and 135 water bird species. An assessment of fisheries documented 76 fish species of which $43 \%$ were caught exclusively in monofilament gill nets, a gear known to kill dolphins by entanglement. Eight new records of fishes preyed upon by Ganges river dolphins were identified from the stomach contents of two dolphin carcasses (Setipinna brevifilis, Osteobrama cotio cotio, Puntius sophore, Crosochelius latius, Mystus cavasius,
\end{abstract}

Heteropneustus fossilis, Macrognathus pancalus, Sperata seenghala). These fishes and other species previously recorded in the diet of the dolphins composed 33.3\% of the total catch sampled in 2001-2003. Interviews of 108 fishing households revealed that literacy rates were low (29.9\%) and almost 50\% earned less than USD 411 per year. The most important conservation actions that could be taken are for national and state governments to establish civil control and promote the development of community-based fishing cooperatives. These cooperatives could enjoy ownership rights to certain river segments in exchange for employing sustainable fishing techniques that are less injurious to dolphins.

Keywords Fisheries management, Ganges river dolphin, India, Platanista gangetica gangetica, protected areas, threats.

This paper contains supplementary materials that can only be found online at http:/ /journals.cambridge.org

\section{Introduction}

Protected areas often exist in name only, and their size, location, and configuration are determined without consideration or in depth knowledge of the environmental requirements of the species they are intended to protect. In August 1991, the Government of Bihar, India designated a c. $60 \mathrm{~km}$ segment of the Ganges River between Sultanganj to Kahalgaon as the Vikramshila Gangetic Dolphin Sanctuary under authority conferred by the federal government in the Wildlife Protection Act of 1972. The Sanctuary is the only protected area established specifically for the protection of Ganges river

Sunil K. Choudhary, Subhasis Dey, Sushant Dey and Satya Prakash Vikramshila Biodiversity Research and Education Centre, T.M. Bhagalpur, University, Bhagalpur 812007 Bihar, India.

Brian D. Smith* (Corresponding author) Marine Program, Wildlife Conservation Society, 2300 Southern Boulevard, Bronx, New York, 10460, USA. E-mail bsmith@wcs.org

*Current address: 27/16 Soi Naya, Moo1, Muang, Rawai 83130 Phuket, Thailand

Received 13 September 2004. Revision requested 26 January 2005. Accepted 13 June 2005 dolphins or susus Platanista gangetica gangetica. This obligate freshwater dolphin is categorized as Endangered on the IUCN Red List due to decline in both its range and population size (IUCN, 2004). However, no protective measures were implemented and, until recently, river stakeholders remained generally unaware of the existence of the Sanctuary.

The Ganges river dolphin is discontinuously distributed in the Ganga-Brahmaputra-Meghna and KarnaphuliSangu river systems of South Asia from the base of the Himalayan foothills to the Bay of Bengal (Mohan, 1989; Sinha, 1997; Smith et al., 1998; Sinha et al., 2000). Extensive population fragmentation has resulted from the widespread construction of barrages (low gated dams; Smith \& Reeves, 2000a; Smith et al., 2000). Although there is no credible estimate of dolphin abundance for the Ganges system, the largest subpopulation probably occurs between the Farakka Barrage, near the India/Bangladesh border, and barrages in the mainstream and Kosi, Son, Gandak, Ghaghara and Yamuna tributaries, as well as their large affluents, which include the Sanctuary in the Ganges mainstream (Fig. 1). Vessel-based visual surveys of the Sanctuary during the low-water seasons of 1996 and 1998 counted a minimum of 92 and 81 dolphins, respectively (Sinha et al., 2000). 


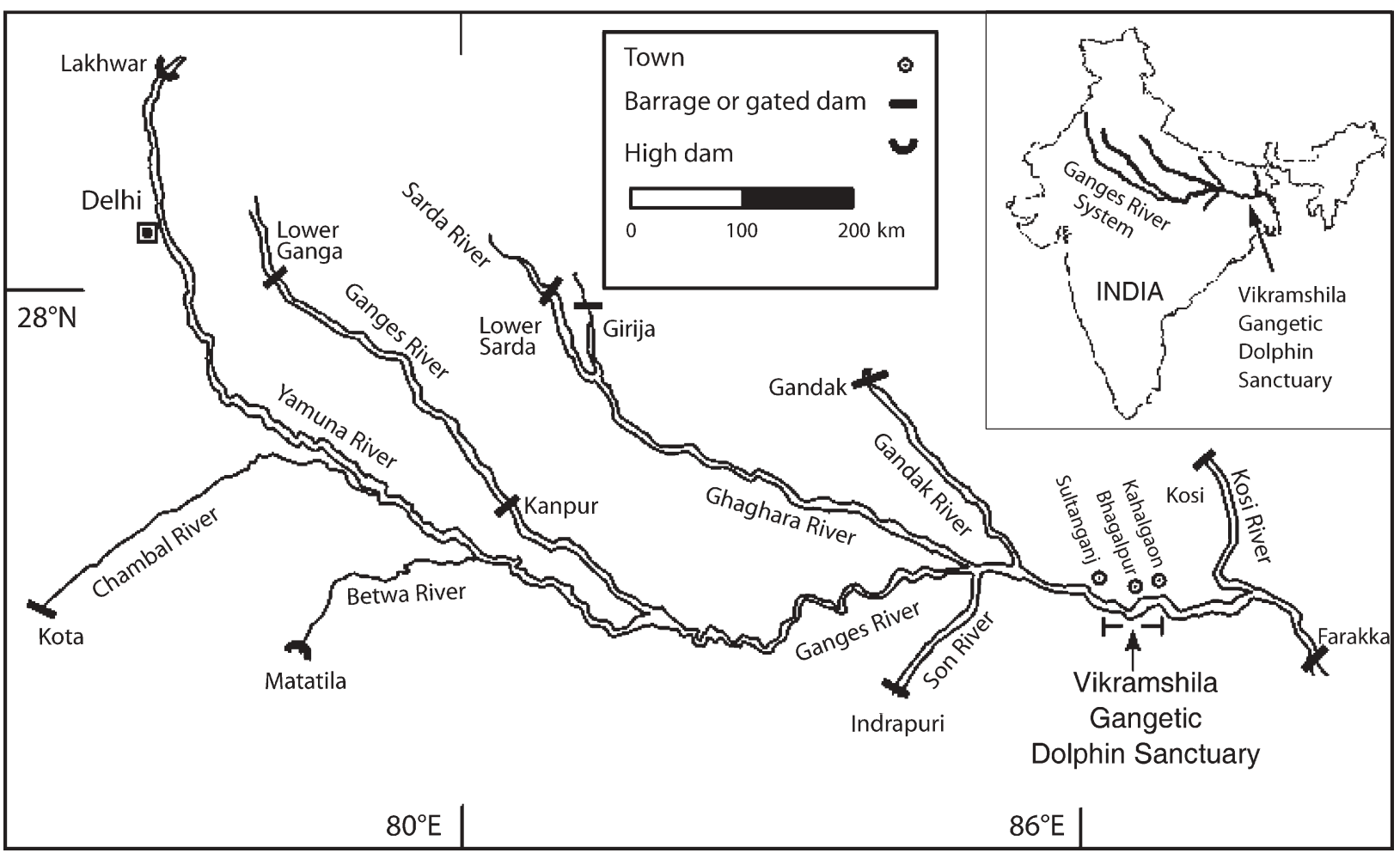

Fig. 1 Map of the Ganges River in India showing the locations of the Vikramshila Gangetic Dolphin Sanctuary and major dams and barrages that interrupt dolphin movements.

Here we report the ongoing conservation and monitoring programme in the Sanctuary conducted by the Vikramshila Biodiversity Research and Education Centre. The programme aims to (1) estimate the minimum and relative abundance of Ganges river dolphins, (2) document the occurrence of other wildlife, (3) assess fish diversity and fisheries, with particular emphasis on dolphin prey and fishing gears known to threaten dolphins, (4) evaluate local threats to the long-term viability of the dolphins and other wildlife, (5) investigate the socioeconomic conditions of local fishing communities, and (6) develop and promote recommendations for conserving wildlife and promoting sustainable fisheries.

\section{Study Area}

Active braided channels, meanders, and oxbow lakes, which result from dynamic hydrological processes occurring within a low gradient alluvial plain, characterize the geomorphology of the Sanctuary. Water levels rise as much as $10 \mathrm{~m}$ and the main channel widens to 5$6 \mathrm{~km}$ during the monsoon season. The mean discharge from January 1965 to December 1973 at Farakka Barrage, $145 \mathrm{~km}$ below the Sanctuary, was 11,558 \pm SD $14,553 \mathrm{~m}^{3} \mathrm{~s}^{-1}$ (range 1,181-65,072; hydrological data after construction of the barrage are held confidential by the Indian government), with the lowest discharge during February-May and the highest during JulyOctober (Vörösmarty et al., 1998). Monadnocks or rock islands induce large counter-current pools, the primary habitat of river dolphins (Smith, 1993), at the upstream and downstream ends of the Sanctuary in Sultanganj and Kahalgaon, respectively. In the last several decades increasing urbanization, flood plain agriculture, and the construction of barrages for irrigation and flood control have caused dramatic changes in the flow regime and geomorphology of the Ganges mainstream.

\section{Methods}

\section{Dolphin surveys and prey investigation}

From March 2001 to December 2003 we assessed the low-water season abundance and distribution of Ganges river dolphins in the Vikramshila Gangetic Dolphin Sanctuary. Eight vessel-based visual surveys for dolphins were conducted of the entire length of the Sanctuary in both upstream and downstream directions using motorized boats. Two primary observers, one each on the right and left sides of the vessel searched by eye in a 90-degree cone in front of the vessel. A third observer served as data recorder and also searched for dolphins when not filling out the data forms. Two independent observers positioned behind the primary observers 
recorded any sightings missed by the primary team. Sightings made by the primary and secondary teams were pooled for calculating encounter rates and the best minimum abundance estimate. A global positioning system was used to record the distance travelled and the geographical coordinates of dolphin sightings.

Group sizes were recorded according to best, high and low estimates. This allowed us to evaluate sightings in terms of a range of abundance estimates, rather than an absolute count, which would not reflect the inherent uncertainty about the actual number of animals present in a certain area (Smith \& Reeves, 2000b). We avoided double counts by maintaining close communication among the primary observers and, for some sightings, we used a zero for our low and occasionally best group size estimates if there was a possibility that the animals had already been counted (Smith et al., 1994). The number of calves, defined as <1.0 m long (Brownell, 1984), was also recorded. This relatively simple direct count survey technique was selected because of the need for a standardized methodology that could be economically and consistently applied by a small team to monitor long-term population trends.

Dolphin carcasses were recovered on an opportunistic basis and their stomach contents examined for identification of prey. Undigested fishes were identified to species according to Talwar \& Jhingran (1991) and Srivastava (1994) with modifications to nomenclature from Fishbase (2005).

\section{Observations of other wildlife}

During the dolphin surveys a separate observer searched for water birds and terrestrial and other aquatic wildlife (in addition to dolphins) using the naked eye and binoculars. Data were recorded on the species, location and the number of individuals. Bird identifications were made using Ali (1979), Ali \& Ripley (1978-1980), Sonobe \& Usui (1993) and Grimmet et al. (1999).

\section{Fisheries assessment}

We conducted fish surveys at landing sites (five in Bhagalpur and two in Kahalgaon) and markets (three in Bhagalpur and one in Kahalgaon) for 5 days each month. Both landing sites and markets were surveyed because some of the fish at landing sites were sold on the spot and some of the fish in the markets were landed at sites that we were unable to survey. We avoided double counting fish by recording the identity of individual fishermen at landing sites and checking who sold the fish to each trader at the markets. Catches were sorted according to species. Identifications were made using Talwar \& Jhingran (1991) and Srivastava (1994), again with modifications to nomenclature according to Fishbase (2005).
The catch weight of each species was visually estimated or measured on a balance. Voucher specimens were archived at the Vikramshila Biodiversity Research and Education Center. Fishermen were interviewed at landing sites to determine what types of gears were used to catch each species and how many fishermen were involved in fishing. During the interviews the names of fishermen and the boats they operated from were recorded to count the total number of fishermen and boats operating in the area.

\section{Socioeconomic survey}

We conducted a socioeconomic survey of fishermen living along the banks of the river in Sultanganj, Bhagalpur and Kahalgaon. The questionnaire included questions on the number of persons in each household and their education, property, sources of drinking water, and income (Appendix 1). Households were chosen at random for the interviews. Although a strict social science protocol was not necessarily followed, interviews with fishermen were conducted by members of the research team, who have maintained a long-term supportive presence in local riverine communities, and in a manner that was respectful of local values, perceptions and traditions.

\section{Results}

\section{Dolphin surveys and prey investigation}

Mean encounter rates calculated from the best estimates of group size were 1.8 dolphins $\mathrm{km}^{-1}$ (range 1.4-2.8) and 1.2 dolphins $\mathrm{km}^{-1}$ (range $0.8-2.3$ ) for the eight upstream and eight downstream surveys, respectively (Table 1). Upstream counts were significantly different from downstream counts $\left(\chi^{2} \mathrm{P}<0.001, \mathrm{df}=1\right)$, with upstream counts averaging $66.1 \%$ greater (range 4.1-135.1\%) than downstream. The overall mean survey speed was $9.0 \mathrm{~km} \mathrm{~h}^{-1}$ (range 8.1-10.0) for downstream and $5.0 \mathrm{~km} \mathrm{~h}^{-1}$ (range 4.1-6.2) for upstream surveys. The mean count for all upstream surveys was $119 \pm$ SD 31.8 dolphins (range 88-174) based on the sum of best estimates of group size for both primary and secondary observers. Counts based on the sum of the low and high estimates of group size were on average $0.7 \%$ lower and $5.8 \%$ higher, respectively. The mean percentage of sightings missed by the primary observers but detected by the secondary observers was $25.5 \%$ (range $1.7-54.9$ ). The percentage of observed neonates was relatively high during the surveys conducted in March 2002 (25.2 and $25.3 \%$ for upstream and downstream surveys, respectively) and low for those conducted in March 2001 (1.3 and $2.7 \%$ for upstream and downstream surveys, respectively). 
Table 1 Summary of dolphin survey effort and sightings for surveys in the Vikramshila Gangetic Dolphin Sanctuary during 2001-2003.

\begin{tabular}{|c|c|c|c|c|c|c|c|c|c|c|}
\hline \multirow{2}{*}{$\begin{array}{l}\text { Date (survey } \\
\text { direction)* }\end{array}$} & \multirow{2}{*}{$\begin{array}{l}\text { Survey } \\
\text { distance } \\
(\mathrm{km})\end{array}$} & \multirow{2}{*}{$\begin{array}{l}\text { Vessel } \\
\text { speed } \\
\left(\mathrm{km} \mathrm{h}^{-1}\right)\end{array}$} & \multirow{2}{*}{$\begin{array}{l}\text { Sightings by } \\
\text { primary } \\
\text { observers }\end{array}$} & \multirow{2}{*}{$\begin{array}{l}\text { Sightings by } \\
\text { secondary } \\
\text { observers }\end{array}$} & \multicolumn{3}{|c|}{$\begin{array}{l}\text { Sum of group size } \\
\text { estimates from primary \& } \\
\text { secondary sightings }\end{array}$} & \multirow{2}{*}{$\begin{array}{l}\text { Sightings } \\
\mathrm{km}^{-1}\end{array}$} & \multirow{2}{*}{$\begin{array}{l}\text { Dolphins } \\
\mathrm{km}^{-1}\end{array}$} & \multirow{2}{*}{$\begin{array}{l}\text { Number } \\
\text { of } \\
\text { Calves (\%) }\end{array}$} \\
\hline & & & & & Best & High & Low & & & \\
\hline Mar. 2001 (U) & 64.9 & 4.9 & 90 & 5 & 154 & 161 & 154 & 1.4 & 2.4 & $2(1.3)$ \\
\hline Mar. 2001 (D) & 64.0 & 8.6 & 88 & 2 & 148 & 150 & 148 & 1.4 & 2.3 & $4(2.7)$ \\
\hline May 2001 (U) & 62.9 & 4.1 & 57 & 1 & 103 & 107 & 103 & 0.9 & 1.6 & $12(11.7)$ \\
\hline May 2001 (D) & 62.0 & 8.3 & 34 & 1 & 53 & 55 & 53 & 0.6 & 0.9 & $11(21.0)$ \\
\hline Dec. 2001 (U) & 63.2 & 5.2 & 52 & 24 & 174 & 184 & 174 & 1.2 & 2.8 & $32(18.4)$ \\
\hline Dec. 2001 (D) & 58.0 & 9.5 & 23 & 28 & 74 & 77 & 74 & 0.9 & 1.3 & $1(1.3)$ \\
\hline Mar. 2002 (U) & 66.0 & 4.9 & 40 & 24 & 103 & 110 & 103 & 1 & 1.6 & $26(25.0)$ \\
\hline Mar. 2002 (D) & 63.5 & 10.0 & 22 & 26 & 91 & 92 & 90 & 0.8 & 1.4 & $23(25.3)$ \\
\hline May $2002(\mathrm{U})$ & 63.5 & 4.8 & 44 & 18 & 138 & 147 & 129 & 1.0 & 2.2 & $24(17.5)$ \\
\hline May 2002 (D) & 59.1 & 8.1 & 24 & 15 & 74 & 77 & 71 & 0.7 & 1.3 & 13 (17.6) \\
\hline Mar. 2003 (U) & 65.2 & 6.2 & 41 & 13 & 103 & 112 & 103 & 0.8 & 1.6 & $16(15.5)$ \\
\hline Mar. 2003 (D) & 63.2 & 8.7 & 28 & 15 & 65 & 68 & 64 & 0.7 & 1.0 & $12(18.5)$ \\
\hline June 2003 (U) & 65.1 & 4.9 & 37 & 6 & 88 & 94 & 88 & 0.6 & 1.4 & $12(13.6)$ \\
\hline June 2003 (D) & 63.7 & 10.0 & 23 & 9 & 51 & 52 & 51 & 0.5 & 0.8 & $8(15.7)$ \\
\hline Dec. 2003 (U) & 66.0 & 5.3 & 33 & 12 & 92 & 88 & 92 & 0.7 & 1.4 & $6(6.5)$ \\
\hline Dec. 2003 (D) & 64.3 & 9.1 & 20 & 9 & 56 & 59 & 55 & 0.5 & 0.9 & $5(8.9)$ \\
\hline
\end{tabular}

${ }^{*} \mathrm{U}$, upstream; D, downstream.

We recovered two dolphin carcasses, in January 2000 and January 2001. Nine fish species were identified from undigested stomach contents: Setipinna brevifilis (known locally as phasia), Osteobrama cotio cotio (pithari), Puntius sophore (pothia), Crosochelius latius (gahuma), Mystus cavasius (palwa), Heteropneustus fossilis (singhi), Parambassis ranga (chanda), Macrognathus pancalus (gainchi) and Sperata seenghala (tagwa aria). Eight of these were new records for the prey of Ganges river dolphins; the additional species $P$. ranga was reported in Sinha et al. (1993) by its junior synonym Chanda ranga. Fish lengths were $3.5-20 \mathrm{~cm}$ of which the longest was $S$. seenghala.

\section{Observations of other wildlife}

We documented a rich diversity of other threatened aquatic wildlife (Appendix 2). Except for the softshell turtle Aspideratus gangeticus all chelonians were identified from discarded shells or collected live from local fishermen. The single gharial Gavialis gangeticus observed in January 2002 was reported to have been killed by poachers in May 2002. We rescued an Indian smoothcoated otter Lutrogale perspicillata pup from poachers during a field trip in 2001. We recorded 135 bird species including 57 species of resident $(42.2 \%), 49$ species of resident migrants (36.3\%) and 29 species of true migrants (21.5\%; Appendix 3). On two occasions we observed the greater adjutant stork Leptoptilos dubius, an Endangered species (IUCN, 2004) that had never before been recorded in the Ganges Basin (Choudhary et al., 2004).

\section{Fisheries assessment}

Seventy six fish species belonging to 10 Orders and 26 Families were recorded during 2001-2003 (Appendix 4), $43 \%$ caught exclusively in monofilament gill nets, $15.8 \%$ in basket nets, $1.3 \%$ on hook and line, $22.4 \%$ in both monofilament gill nets and basket nets, $9.2 \%$ in monofilament gill nets and by hook and line, $2.6 \%$ in monofilament gillnets, basket nets and by hook and line, and one species, Rhinomugil corsula, in carpet nets and another, Clupisoma garua, using dolphin oil as an attractant (see below). Of the 76 fish species recorded 44 , including five identified as dolphin prey (S. brevifilis, P. sophore, M. cavasius, H. fossilis and S. seenghala), were economically important (market price $>$ INR $15 \mathrm{~kg}^{-1}$ or USD $\left.0.32 \mathrm{~kg}^{-1}\right)$. Two genera of crustaceans were recorded, Penaeus spp. and Macrobrachium spp., the former caught in basket nets and large mosquito nets and the latter caught in gill nets. Species identified as dolphin prey by Reeves et al. (1993) and during this study, constituted 29.1, 33.6 and $37.1 \%$ of the sampled catch in 2001-2003, respectively (Appendix 4).

Fishing intensity was high throughout the year but with peak periods during the low-water season from October to February. In Kahalgaon there were 324 fishermen using 106 boats and in Bhagalpur 125 fishermen using 56 boats. These fishermen operated in a c. $10 \mathrm{~km}$ river segment adjacent to their landing sites. We recorded seine nets (10-15 $\mathrm{mm}$ mesh size), gill nets (15-315 mm mesh size; although gill nets with a mesh 
size $<40 \mathrm{~mm}$ were banned in a 1992 Gazette Notification), large mosquito nets (1 mm mesh size), long lines with multiple hooks, plunge baskets and bamboo barrier traps. Gill nets made of nylon threads were the most commonly used gear followed by long lines. Large mesh $(>10 \mathrm{~cm}$ ) gill nets were found drifting in the mainstream during the low-water season from January to mid April. Basket nets were used only during the monsoon months. In the post monsoon season fishermen often barricaded channel mouths with bamboo. Scoop nets were used in counter currents from November to May. Mosquito nets were frequently observed being used to catch small fish and carp spawn for aquaculture purposes. Carpet nets made of plant material (c. $8 \mathrm{~m}$ long and $2 \mathrm{~m}$ wide) were also used to catch small fish in side channels.

\section{Socioeconomic survey}

Interviews were conducted of 108 households (Table 2). Of these $85.2 \%$ depended completely on fishing for their livelihood, with the rest working as part-time fishermen or fish traders. Women contributed significantly to fish trading. The majority of fishermen owned their own boats $(62.0 \%)$ and nets $(88.9 \%)$. Literacy rates were low (29.9\%) with less than $11 \%$ of the people living in fishing communities with access to primary education. The majority of households depended on the river for drinking water $(52.8 \%)$ with the percentages much higher in Sultanganj and Kahalgoan. Almost $50 \%$ of households made less than INR 20,000 (USD 411) per year.

\section{Discussion}

\section{Dolphin surveys and prey investigation}

Our dolphin encounter rates in the Vikramshila Gangetic Dolphin Sanctuary compare favourably to other areas where the species has been surveyed using similar techniques. For example, the encounter rate for a downstream survey of a comparable segment in the middle Brahmaputra River between Guwahati and Goalpara in India was 0.30 dolphins $\mathrm{km}^{-1}$ during April 1999 (B.D. Smith, unpubl. data) and 0.76 dolphins $\mathrm{km}^{-1}$ for downstream surveys in the Karnaphuli-Sangu Rivers of Bangladesh from January to April 1999 (Smith et al., 2001). The large difference in the proportion of neonates observed during March 2001 versus March 2002 may be accounted for by the apparent preference of cow-calve pairs to congregate in large counter-current pools and the fact that the availability of these features varies in different river segments from year to year.

Overall the pattern of dolphin occurrence was consistent with a preference for reaches characterized by complex morphological features that induce hydraulic
Table 2 Socioeconomic data for fishing communities in Sultanganj, Bhagalpur and Kahalgaon (Fig. 1).

\begin{tabular}{|c|c|c|c|}
\hline & Sultanganj & Bhagalpur & Kahalgaon \\
\hline No. households surveyed & 31.0 & 28.0 & 49.0 \\
\hline $\begin{array}{l}\text { Mean no. of persons per } \\
\text { household }\end{array}$ & 7.2 & 7.5 & 6.1 \\
\hline \multicolumn{4}{|l|}{ Education } \\
\hline$\%$ persons primary education & 9.0 & 12.4 & 10.4 \\
\hline$\%$ persons secondary education & 2.2 & 3.3 & 3.0 \\
\hline$\%$ persons college education & 0.0 & 2.9 & 0.3 \\
\hline$\%$ persons adult education & 1.3 & 2.4 & 7.0 \\
\hline$\%$ persons illiterate & 78.0 & 63.8 & 68.6 \\
\hline \multicolumn{4}{|l|}{ Occupation } \\
\hline$\%$ households full-time fishing & 93.5 & 96.4 & 73.5 \\
\hline$\%$ households part-time fishing & 0.0 & 0.0 & 12.2 \\
\hline$\%$ households fish traders & 6.5 & 3.6 & 14.3 \\
\hline \multicolumn{4}{|l|}{ Property } \\
\hline$\%$ households own boat & 83.9 & 75.0 & 40.8 \\
\hline$\%$ households own fishing nets & 87.1 & 78.6 & 95.9 \\
\hline Average no. nets per family & 6.5 & 5.6 & 4.9 \\
\hline \multicolumn{4}{|l|}{ Source of drinking water } \\
\hline $\begin{array}{l}\% \text { households depending } \\
\text { completely on river }\end{array}$ & 12.9 & 0.0 & 44.9 \\
\hline $\begin{array}{l}\% \text { households depending on } \\
\text { river but supplemented by } \\
\text { tube well or city supply }\end{array}$ & 77.4 & 0.0 & 14.3 \\
\hline $\begin{array}{l}\text { No. households not depending } \\
\text { on river }\end{array}$ & 9.7 & 100.0 & 40.8 \\
\hline \multicolumn{4}{|l|}{ Household income per year* } \\
\hline INR 1,000-5,000 (USD 23-115) & 3.2 & 3.6 & 0.0 \\
\hline $\begin{array}{l}\text { INR 5,001-10,000 } \\
\text { (USD 115-206) }\end{array}$ & 16.1 & 21.4 & 4.1 \\
\hline $\begin{array}{l}\text { INR 10,001-20,000 } \\
\text { (USD 206-411) }\end{array}$ & 35.5 & 42.9 & 28.6 \\
\hline $\begin{array}{l}\text { INR 20,001-30,000 } \\
\text { (USD 411-617) }\end{array}$ & 22.6 & 25.0 & 26.5 \\
\hline $\begin{array}{l}\text { INR 30,001-40,000 } \\
\quad \text { (USD 617-823) }\end{array}$ & 16.1 & 3.6 & 12.2 \\
\hline $\begin{array}{l}\text { INR 40,001-50,000 } \\
\text { (USD 823-1,029) }\end{array}$ & 3.2 & 3.6 & 10.2 \\
\hline $\begin{array}{l}\text { INR 50,001-60,000 } \\
\quad \text { (USD 1,029-1,235) }\end{array}$ & 3.2 & 0.0 & 10.2 \\
\hline INR > 60,000 (>USD 1,235) & 0.0 & 0.0 & 8.2 \\
\hline
\end{tabular}

*Conversion based on Jan. 2004 exchange rate of INR $48.6=$ USD 1.

heterogeneity and bottom scouring (Smith, 1993; Smith, et al., 1998, 2001). Dolphins were also frequently sighted in large groups of up to 13 individuals in counter-current pools induced by pilings of the Vikramshila Bridge, just downstream from Bhagalpur, and the three monadnocks of Kahalgaon. Large counter-current pools were also the primary sites for fishing, ferry crossings, sewage disposal and religious and domestic bathing (both animals and humans). The same conditions that make these areas suitable for dolphins (i.e. hydraulic refuge and abundant fish) also make them desirable sites for human use.

The higher counts for the upstream surveys can be explained by the greater number of opportunities (i.e. 
surfacings) for detecting dolphins when surveying at a slower speed. The relatively large number of sightings missed by the primary observers but detected by secondary observers indicated that the actual number of dolphins occurring in the Sanctuary is probably greater than our minimum abundance estimates (Marsh \& Sinclair 1989), even though we included the secondary observer sightings. During future surveys we intend to use an equal number of observers on each team and switch them halfway through the survey so that we can estimate visibility bias with a one-way independent observer model (Cook \& Jacobsen, 1979).

\section{Fisheries assessment}

Large seine nets (mesh size $10-15 \mathrm{~mm}$ ) and mosquito nets (mesh size $1 \mathrm{~mm}$ ) are operated illegally and under the patronage of criminals. These activities threaten the livelihoods of fishermen using legal techniques and reduced the availability of dolphin prey. Fishing is banned from June to August during the breeding period of many fishes but violations are common.

The species composition of fish catch landed at Bhagalpur, near the middle of the Sanctuary, is believed to have changed dramatically in recent years, with low economic value catfishes (e.g. Sperata (Mystus) aor, $S$. seenghala and Wallago attu) and other miscellaneous species replacing high value carps (e.g. Cirrhinus cirrhosus, Labeo rohita, Catla catla and Tinualosa (Hilsa) ilisha; Jhingran \& Ghosh, 1978; Natrajan, 1989). This change can probably be explained by interrupted fish migrations (in the mainstream by barrages and on and off the floodplain by embankments; Reeves \& Smith, 1999) and overexploitation of carp spawn in extremely small mesh (mosquito) nets, which results in a massive bycatch of fish fingerlings.

\section{Threats to wildlife}

Fishermen occasionally used harpoons to spear large fish and possibly dolphins. We also received reports of dolphins being intentionally caught with a small-mesh seine net and observed these nets being used close to where dolphins were surfacing. In January 1999, before the present project began, we recovered the penis of a male Ganges river dolphin being sold illegally at a remote fish market in the Nathnagar $(10 \mathrm{~km}$ upstream from Bhagalpur). We were told that the body was sold for c. INR 1,000 to be rendered for oil for use as a fish attractant (see below). The penis was dried with the intention of grinding it up to be sold as an aphrodisiac.

Although we have no quantitative data on the number of dolphin catches, either deliberate or incidental, mortality in fishing gear, especially gillnets, is known to be a severe problem for Ganges river dolphins throughout most of their range (Smith \& Reeves, 2000c). They may be particularly vulnerable to entanglement in gillnets because their preferred habitat is often in the same location as preferred fishing grounds. Also, the demand for dolphin carcasses is high because dolphin oil is valued as a fish attractant for the schilbeid catfishes Clupisoma garua and Eutropicthys vacha (Motwani \& Srivastava, 1961; Smith et al., 1998; Bairagi, 1999; Sinha, 2002). This fishing practice creates a market for dolphin products (dolphin oil sells for USD $5-6 \mathrm{~kg}^{-1}$ in local markets) and therefore an incentive for killing dolphins found accidentally caught in fishing nets but still alive, and setting nets strategically in the hope of capturing the animals (termed 'assisted incidental capture' by Sinha, 2002).

Turtles were observed being caught throughout the Sanctuary, most frequently by fishermen from Kahalgaon, with long lines and multiple hooks $(4 \mathrm{~cm}$ shank, 350-400 hooks per line and attached to $45 \mathrm{~cm}$ long leaders) known as hajaria bansi or katia bansi. The dried shells were smuggled to Bangladesh to be used for medicinal purposes and the meat was sold clandestinely in local markets. Fishermen from the neighbouring state of Jharkhand used a different method to catch turtles. They built hides on the sand banks and caught the turtles with long bamboo poles ( 6 or 7 lashed together for a total length of $12-17 \mathrm{~m}$ ) with a large hook (35 cm shank) attached to the end for snagging the animals. Birds were poached using poison, guns, nets and snares. Sedativelaced grains were also placed in areas particularly frequented by ducks and storks with the intention of capturing them alive because of the higher price that living birds command in local markets.

\section{Socioeconomic considerations}

Bihar is among the most impoverished states and it has the lowest literacy rate (47.5\%) in India (Anon, 2003). Children of the fishing families in the Sanctuary do not normally attend school because all members of the household must work to survive. Public schools also do not meet basic educational needs due to a lack of infrastructure and corrupt management.

Historically, fishermen in the Ganges of Bihar were required to pay a Panidar or waterlord for the right to fish. This arrangement prevailed for at least a century until the fishermen were encouraged by a local NGO, Ganga Mukti Andolan, to free themselves from the dominion of the waterlords. Over an 8-year period, the fishermen and their families were harassed, often violently, by the Panidars. Finally the government abolished the century-old lease agreement and the fishermen were given the right to fish freely in the river. Soon afterwards gangs took control of the Sanctuary. Their 
dictum prevails and fishermen are required to turn over a substantial portion of their catch (as much as 50\%) to these gangs in exchange for 'protection' from harassment, beatings and killings. Fishermen regularly employ unsustainable fishing practices in a bid to provide for their families while at the same time paying the criminal gangs. The threat of violence is real. These criminals twice interrogated our research team at gunpoint. During the early stages of the project research activities were suspended after seven fishermen were executed in the Sanctuary for refusing to give the gangs a portion of their catch. Organized massacres of rural villagers in response to tenure protests are a common and tragic occurrence in Bihar (Human Rights Watch, 1999).

\section{Conservation}

Establishing an effective wildlife sanctuary is a challenging task. This is especially true in a dynamic environment such as the Ganges River, where flood cycles cause massive changes in the landscape, both seasonally and annually. The challenge is also great because resources within the Sanctuary support one of the world's most economically impoverished human populations. Our biomonitoring results indicate that the Vikramshila Gangetic Dolphin Sanctuary supports a relatively high density of dolphins and a rich diversity of other fauna, and that if protective measures were effectively implemented it could contribute substantially towards conserving a number of key biodiversity elements of the Ganges system.

We believe that the most meaningful conservation action that should be taken in the Sanctuary is for national and state governments to establish civil control and promote the development of community-based fishing cooperatives. Lack of well defined property rights and uncertainty of continued access are strong disincentives for conserving fishery resources (Berkes, 1985). Giving management responsibilities to local stakeholders at the community level fosters accountability and increases motivation for conservation (Mangel et al., 1996). Ownership rights to certain river segments should be conferred on these cooperatives, on the condition that they only employ sustainable fishing techniques that are less injurious to aquatic wildlife.

Gillnets are problematical because from an economic perspective their use is of primary importance to impoverished fishing communities. Other gears catch fewer fish (lower numbers or smaller sized ones of lesser value) and their use are limited by where and when they can be operated (e.g. lift and scoop nets need particular areas where small fish swim close to the bank in counter currents and the availability of these areas varies both seasonally and annually). Regulations for gillnets should include (1) strictly limiting their numbers and configurations (e.g. five per family with a mesh size of no less than $24 \mathrm{~mm}$ and a length and width of no more than 150 and $7 \mathrm{~m}$, respectively, and these numbers may need to be adjusted if additional families enter the gill net fishery or if biomonitoring shows that the sustainability of wildlife and fisheries continues to be threatened), and (2) requiring fishermen to monitor their nets and release wildlife bycatch if entangled. Additionally, the existing ban on fishing with chemicals (e.g. DDT) must be followed, and barricade fishing in smaller channels during flood recession should be prohibited.

A monitoring programme would be needed to ensure that fishing cooperatives were managing their segment responsibly and according to agreed guidelines. The success of these cooperatives would depend upon the ability of the government to ensure that the river is kept free from criminals and on educating fishermen that their tenure rights are contingent upon responsible stewardship.

Significant progress has been made on promoting these conservation recommendations. In 2001 the Patna High Court (C.J.W.C. No. 5628) directed state and federals governments to allocate funds for supporting dolphin conservation efforts in Bihar. In 2002, the Vikramshila Biodiversity Research and Education Centre convened the Regional Seminar on Environmental Laws in the Vikramshila Gangetic Dolphin Sanctuary, Bhagalpur, India (Anon, 2002). In 2004, the State Wildlife Board of Bihar formed a management committee for the Vikramshila Gangetic Dolphin Sanctuary. With increased patrolling and people's participation there has been an apparent decline in intentional killings of dolphins and other aquatic wildlife, and local fishermen have started to form cooperatives to lobby for increased security and better fisheries management. Cooperation among regulatory authorities, NGOs and local fishermen will be essential for bringing science and community-based management to the sanctuary. Important first steps have been made. Our challenge now is to strengthen these efforts.

\section{Acknowledgements}

We gratefully acknowledge financial assistance from the Whale and Dolphin Conservation Society (WDCS) and the Wildlife Conservation Society (WCS). Special appreciation goes to Alison Smith, Vanessa Williams and Jess Feghali from WDCS, and Liz Lauck and Rebecca Cerroni from WCS for championing the project and for organizing the funds. We also thank volunteers from the Department of Botany, T.M. Bhagalpur University and boatmen of Sultanganj, Bhagalpur and Kahalgaon who assisted us during the surveys. We appreciate field assistance from Bhagirath Gope and Arun Mitra. 


\section{References}

Ali, S. (1979) The Book of Indian Birds. Oxford University Press, Bombay, India.

Ali, S. \& Ripley, S.D. (1978-80) Handbook of the Birds of India and Pakistan (10 volumes). Oxford University Press, New Delhi, India.

Anon (2002) Proceedings of Regional Seminar on Environmental Laws: Violations and Regulations in Vikramshila Gangetic Sanctuary (November 30, 2002). Unpublished report. Vikramshila Biodiversity Research \& Education Centre, University Department of Botany, T.M. Bhagalpur University, Bhagalpur (Bihar), India.

Anon (2003) Bihar Development Report 2003: Summary and Conclusions. Indian Institute for Human Development, New Delhi, India.

Bairagi, S.P. (1999) Oil bait fishing of cat fishes in Brahmaputra River affecting river dolphin populations in Assam, India. Journal of the Bombay Natural History Society, 96, 424-426.

Berkes, F. (1985) Fishermen and the tragedy of the commons. Environmental Conservation, 12, 199-206.

Brownell, Jr, R.L. (1984) Review of reproduction in platanistoid dolphins. Reports of the International Whaling Commission (Special Issue), 6, 149-160.

Choudhary, S.K., Dey, S., Dey, S. \& Mitra, A. (2004) Sighting of the Greater Adjutant Stork Leptoptilos dubius in Vikramshila Gangetic Dolphin Sanctuary, Bihar, India. Journal of the Bombay Natural History Society, 101, 313.

Cook, R.D. \& Jacobson, J.O. (1979) A design for estimating visibility bias in aerial surveys. Biometrics, 35, 735-742.

Fishbase (2005) Fishbase, a Global Information System on Fishes. Http:/ / www.fishbase.org/ [accessed on 17 April 2005].

Grimmet, R., Inskipp, C. \& Inskipp, T. (1999) Pocket Guide to the Birds of the Indian Subcontinent. Oxford University Press, New Delhi, India.

Human Rights Watch Reports (1999) India, the Pattern of Abuse: Rural Violence in Bihar and the State's Response. Http:/ /www.hrw.org/reports/1999/india/India994-06.htm [accessed 02 June 2004].

IUCN (2004) 2004 IUCN List of Threatened Species. Http:/ / www.redlist.org [accessed 30 March 2004].

Jhingran, A.G. \& Ghosh, K.K. (1978) The fisheries of the Ganga river system in the context of Indian aquaculture. Aquaculture, 14, 141-162.

Mangel, M., Talbot, L.M., Meffe, G.F., Agardy, M.T., Alverson, D.L., Barlow, J., Botkin, D.B., Budowski, G., Clark, T., Cooke, J., Crozier, R.H., Dayton, P.L., Elder, D.L., Fowler, C.W., Funtowicz, S., Giske, J., Hofman, R.J., Holt, S.J., Kellert, S.R., Kimball, L.A., Ludwig, D., Magnusson, K., Malayang, B.S., Mann, C., Norse, E.A., Northridge, S.P., Perrin, W.F., Perrings, C., Peterman, R.M., Rabb, G.B., Regier, H.A., Reynolds, J.E., Sherman, K., Sissenwine, M.P., Smith, T.D., Starfield, A., Taylor, R.J., Tillman, M.F., Toft, C., Twiss, J.R., Wilen, Jr, J. \& Young, T.P. (1996) Principles for the conservation of wild living resources. Ecological Applications, 6, 338-362.

Marsh, H. \& Sinclair, D.F. (1989) Correcting for visibility bias in strip transect aerial surveys of aquatic fauna. The Journal of Wildife Management, 53, 1017-24.

Mohan, R.S.L. (1989) Conservation and management of the Ganges River dolphin, Platanista gangetica, in India. In Biology and Conservation of the River Dolphins. Occasional Papers of the IUCN Species Survival Commission (eds W.F. Perrin,
R.L. Brownell, Jr, Z. Kaiya \& L. Jiankang), pp. 64-69. IUCN, Gland, Switzerland.

Motwani, M.P. \& Srivastava, C.B. (1961) A special method of fishing for Clupisoma garua (Hamilton) in the Ganges River system. Journal of the Bombay Natural History Society, 58, 285-286.

Natrajan, A.V. (1989) Environmental impact of Ganges Basin development on gene pool and fisheries of the Ganga River System. In Proceedings of International Large River Symposium (ed. D.P. Dodge), pp. 545-560. Canadian Special Publications, Fisheries and Aquatic Sciences, Ottawa, Canada.

Reeves, R.R. \& Smith, B.D. (1999) Interrupted migrations and dispersal of river dolphins: some ecological effects of riverine development. In Proceedings of a Symposium on Animal Migration, Gland Switzerland, 13 April 1997, CMS Technical Series Publication No. 2 (ed. UNEP/CMS), pp. 9-18. Convention on Migratory Species, Bonn, Germany.

Reeves, R.R., Leatherwood, S. \& Mohan, R.S.L. (1993) A Future for Asian River Dolphins, Report from a Seminar on the Conservation of River Dolphins in the Indian Subcontinent. Whale and Dolphin Conservation Society, Bath, England.

Sinha, R.K. (1997) Status and conservation of Ganges river dolphin in Bhagirathi-Hooghly river systems in India. International Journal of Ecology and Environmental Sciences, 23, 343-355.

Sinha, R.K. (2002) An alternative to dolphin oil as a fish attractant in the Ganges River system: conservation of the Ganges River dolphin. Biological Conservation, 107, 253-257.

Sinha, R.K., Das, N.K., Singh, N.K., Sharma, G. \& Ahsan, S.N. (1993) Gut content of the Gangetic dolphin Platanista gangetica. Investigations on Cetacea, 24, 317-321.

Sinha, R.K., Smith, B.D., Sharma, G., Prasad, K., Choudhary, B.C., Sapkota, K., Sharma, R.K. \& Behra, S.K. (2000) Status and distribution of the Ganges Susu Platanista gangetica, in the Ganges river system of India and Nepal. In Biology and Conservation of Freshwater Cetaceans in Asia, Occasional Paper of the IUCN Species Survival Commission No. 23 (eds R.R. Reeves, B.D. Smith \& T. Kasuya), pp. 54-61. IUCN, Gland, Switzerland.

Smith, B.D. (1993) 1990 status and conservation of the Ganges River dolphin (Platanista gangetica) in the Karnali River, Nepal. Biological Conservation, 66, 159-170.

Smith, B.D. \& Reeves, R.R. (eds) (2000a) Report of the workshop on the effects of water development on river cetaceans in Asia, Rajendrapur, Bangladesh, 26-28 February 1997. In Biology and Conservation of Freshwater Cetaceans in Asia, Occasional Paper of the IUCN Species Survival Commission No. 23 (eds R.R. Reeves, B.D. Smith \& T. Kasuya), pp. 15-21. IUCN, Gland, Switzerland.

Smith, B.D. \& Reeves, R.R. (2000b) Survey methods for population assessment of Asian river dolphins. In Biology and Conservation of Freshwater Cetaceans in Asia, Occasional Paper of the IUCN Species Survival Commission No. 23 (eds R.R. Reeves, B.D. Smith \& T. Kasuya), pp. 97-115. IUCN, Gland, Switzerland.

Smith, B.D. \& Reeves, R.R. (eds) (2000c) Report of the second meeting of the Asian River Dolphin Committee, 22-24 February 1997, Rajendrapur, Bangladesh. In Biology and Conservation of Freshwater Cetaceans in Asia, Occasional Paper of the IUCN Species Survival Commission No. 23 (eds R.R. Reeves, B.D. Smith \& T. Kasuya), pp. 1-14. IUCN, Gland, Switzerland. 
Smith, B.D., Ahmed, B., Ali, M.E. \& Braulik, G. (2001) Status of the Ganges river dolphin or shushuk Platanista gangetica in Kaptai Lake and the southern rivers of Bangladesh. Oryx, 35, 61-72.

Smith, B.D., Aminul Haque, A.K.M., Hossain, M.S. \& Khan, A (1998) River dolphins in Bangladesh: conservation and the effects of water development. Environmental Management, 22, 323-335.

Smith, B.D., Sinha, R.K., Regmi, U. \& Sapkota, K. (1994) Status of Ganges river dolphins (Platanista gangetica) in the Karnali, Narayani, and Sapta Kosi rivers of Nepal and India in 1993. Marine Mammal Science, 10, 68-75.

Smith, B.D., Sinha, R.K., Zhou, K., Chaudhry, A.A., Renjun, L., Wang, D., Ahmed, B., Aminul Haque, A.K.M., Sapkota, K. \& Mohan, R.S.L. (2000) Register of water development projects affecting Asian river cetaceans. In Biology and Conservation of Freshwater Cetaceans in Asia, Occasional Paper of the IUCN Species Survival Commission No. 23 (eds R.R. Reeves, B.D. Smith \& T. Kasuya), pp. 22-39. IUCN, Gland, Switzerland.

Sonobe, K. \& Usui, S. (eds) (1993) A Field Guide to the Water birds of Asia. Wild Bird Society of Japan, Tokyo, Japan.

Srivastava, G. (1994) Fishes of U.P. and Bihar. Viswavidyalaya Publications, Varanasi, India.

Talwar, P.K. \& Jhingran, A.G. (1991) Indian Fishes of India and Adjacent Countries. Oxford \& IBH Publishing Co., New Delhi, Bombay \& Calcutta, India.

Vörösmarty, C.J., Fekete, B. \& Tucker, B.A. (1998) River Discharge Database, Version 1.1 (RivDIS v1.0 supplement). Http:/ / www.rivdis.sr.unh.edu/cgi-bin/TileMap [accessed 02 June 04].

\section{Appendices}

The Appendices for this article are available online at http:/ /journals.cambridge.org

\section{Biographical sketches}

Sunil K. Choudhary is a Member of the Bihar State Wildlife Board of India and Director of the Vikramshila Biodiversity Research and Education Centre. He has been teaching and conducting research on wetland ecology for over 25 years, with river dolphins as his primary focus since 1998 . He has also been mapping arsenic concentrations in groundwater sources along the Ganges River.

Brian D. Smith directs the Wildlife Conservation Society's Asian Freshwater and Coastal Cetacean Program and has worked on cetacean conservation projects in Myanmar, Thailand, Nepal, India, Vietnam, Bangladesh and the Philippines. He currently serves as the Asia Coordinator for the IUCN Species Survival Commission Cetacean Specialist Group.

Subhasis Dey, Sushant Dey and Satya Prakash have conducted field work on river dolphins, fisheries and water birds since 1998. Subhasis Dey and Sushant Dey have had their photographs of biodiversity in the Sanctuary published in national and international journals. 